\title{
27. INTERSTITIAL WATER STUDIES, LEG 28
}

\author{
Richard Mann and Joris M. Gieskes, Scripps Institution of Oceanography, La Jolla, California
}

\begin{abstract}
Results of chemical analyses of interstitial water samples recovered during Leg 28 are presented for Sites $265,268,270,272$, and 274. Data are interpreted in terms of possible diagenetic reactions in these sediments. Results from Site 270 indicate the influence of fresh-water input at depth (also at Site 272), and changes in alkalinity values just above basement are paired with large increases in magnesium. The interstitial water data are adequate to indicate sections in the various holes that should be studied in greater detail.
\end{abstract}

\section{INTRODUCTION}

During Leg 28 of Glomar Challenger cruises, interstitial water samples were collected on a routine basis for storage at the Deep Sea Drilling Project archives. We decided to make some detailed analyses of these samples, especially because of the planned extensive efforts for geochemical studies during Leg 35 in the Bellinghausen Sea area of the Antarctic Ocean.

Interstitial water studies can be very useful as indicators of the importance of diagenetic processes occurring in the sediments and/or the underlying igneous basement. They can provide indicators of where reactions that lead to observed compositional changes may occur and what components appear to be involved, but they do not explicitly indicate what reactions do occur (Gieskes, in press). Information on lithologies, mineralogies, physical properties, and sedimentation rates is most helpful in such an analysis of the data. However, much more extensive work on the solid components will be necessary to find and identify the solid components responsible for the observed changes in the chemical composition of the interstitial fluids.

In this paper we restrict ourselves to an analysis of five sites only: Sites 265, 268, 270, 272, and 274 (Figure 1). Only interstitial water analyses have been carried out, so that this report can, at best, serve only as a guide to future research on the solid components. At present such research is not planned in our laboratory.

\section{METHODS}

Samples of interstitial waters are extracted on a routine basis onboard ship, using methods recently described by Manheim and Sayles (1974). Onboard analyses are made for alkalinity (colorimetric titration) and salinity (refractometer), as well as for the $p \mathrm{H}$ of the sample. Then the sample is put into storage, about $50 \%$ in sealed plastic vials and the rest in glass ampoules. Such storage can have adverse effects on labile components such as nutrients (especially ammonia) and trace metals (for instance, manganous ions). In addition, real problems can be caused by high contents of bicarbonate ions (alkalinity $>15 \mathrm{meq} / \mathrm{l}$ ) due to possible precipitation of calcium carbonate (Berner et al., 1970;
Gieskes, 1973). In view of this, we have mixed all samples with alkalinities of $>12 \mathrm{meq} / 1$ with a measured amount of hydrochloric acid in order to redissolve any precipitated calcium carbonate. Of course, in this case, appropriate dilution factors have been used.

Most analytical methods used in this study have previously been published by Gieskes (1974), with appropriate modifications where needed. We would like, however, to describe our dissolved silica method in greater detail, as we consider it the most appropriate modification of the method of Mullin and Riley (1955) for use in interstitial water studies. One of us (R.M.) developed this procedure when he was an undergraduate research fellow with Dr. Fred Sayles at the Woods Hole Oceanographic Institution.

\section{Dissolved Silica}

\section{Reagents}

(Note: Always use deionized, silica-free water.)

Molybdate reagent: Dissolve $4.0 \mathrm{~g}$ of ammonium paramolybdate $\left(\mathrm{NH}_{4}\right) \mathrm{Mo}_{7} \mathrm{O}_{24} \cdot 4 \mathrm{H}_{2} \mathrm{O}$ (preferably fine crystalline) in approximately $300 \mathrm{ml}$ of deionized water using a $500-\mathrm{ml}$ volumetric flask. Add $12.0 \mathrm{ml}$ of concentrated hydrochloric acid $(12 \mathrm{~N})$, mix, and make the volume $500 \mathrm{ml}$ with deionized water. Store in a brown polyethylene bottle, out of direct surilight. The reagent is stable for many months but should be discarded if any white precipitate forms. If unable to store properly, or if time permits, make fresh each run.

Metol-sulfite solution: Dissolve $6.0 \mathrm{~g}$ of anhydrous sodium sulfite, $\mathrm{Na}_{2} \mathrm{SO}_{3}$, in a $500-\mathrm{ml}$ volumetric flask. Add $10 \mathrm{~g}$ of metol (P-methylaminophenol sulfate) and then add deionized water to make $500 \mathrm{ml}$. When the metol has dissolved, filter the solution through a No. 1 Whatman filter paper and store it in a clean glass bottle, preferably of dark glass, which is tightly stoppered. This solution may deteriorate quite rapidly and erratically and should be prepared fresh at least every month.

Oxalic acid solution: Prepare a saturated oxalic acid solution by shaking $50 \mathrm{~g}$ of analytical-grade reagent oxalic acid dihydrate $(\mathrm{COOH})_{2} \cdot 2 \mathrm{H}_{2} \mathrm{O}$, with $500 \mathrm{ml}$ of deionized water. Let stand overnight. Decant the solution from the crystals for use. This solution may be stored in a glass bottle and is stable indefinitely. 


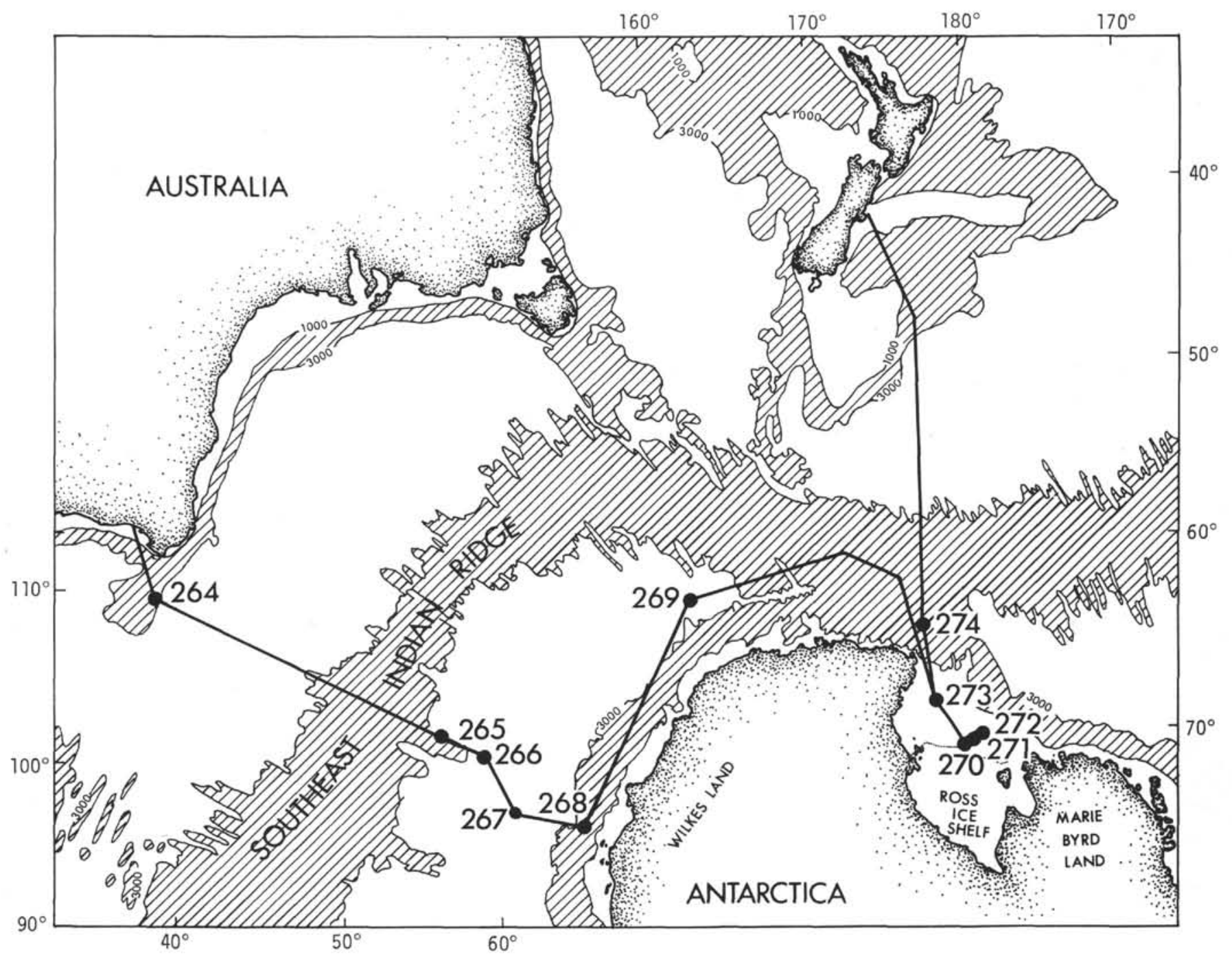

Figure 1. Site location map.

Sulfuric acid solution $\mathbf{5 0} \% \mathrm{~V} / \mathrm{V}$ : Using a $500-\mathrm{ml}$ volumetric flask, pour $250 \mathrm{ml}$ of concentrated analytical reagent-quality sulfuric acid into approximately $200 \mathrm{ml}$ of deionized water. Cool to room temperature and bring volume to $500 \mathrm{ml}$ with a little extra water. Store in polyethylene bottle.

Reducing solution: Mix $50 \mathrm{ml}$ of metol-sulfite solution (\#2) with $30 \mathrm{ml}$ of oxalic acid solution (\#3). Add slowly, with mixing, $30 \mathrm{ml}$ of the $50 \%$ sulfuric acid solution (\#4) and make the mixture a volume of $150 \mathrm{ml}$ with deionized water. This should be made daily, just before using. Multiply above amounts, depending on number of samples, using $3 \mathrm{ml}$ per sample.

Synthetic seawater: Dissolve $25 \mathrm{~g}$ sodium chloride $(\mathrm{NaCl})$ and $8 \mathrm{~g}$ of magnesium sulfate heptahydrate $\left(\mathrm{MgSO}_{4} \cdot 7 \mathrm{H}_{2} \mathrm{O}\right)$ in 11 of deionized water and store in a polyethylene bottle. The silicon content of this solution should not exceed 1 or $2 \mu \mathrm{g}$-at/l.

\section{Silica Standard}

Sodium fluosilicate: Place a small quantity of $\mathrm{Na}_{2} \mathrm{SiF}_{6}$ in an open plastic vial and place in vacuum desiccator overnight to absorb excess water. Do not heat or fuse!
Primary standard: Dissolve $0.5642 \mathrm{~g} \mathrm{Na}_{2} \mathrm{SiF}_{6}$ in a 1-1 Nalgene volumetric flask. Dissolution is slow, so allow at least $30 \mathrm{~min}$. This cannot be rushed. Use deionized distilled water. The concentration of this standard is $3000 \mu \mathrm{g}$-at $\mathrm{Si} / \mathrm{l}$. Store in $500-\mathrm{ml}$ polyethylene bottle. The standard is stable indefinitely.

Dilutions from primary standard: When making dilutions, use distilled water and store in poly containers. A group of dilutions ranging from 30 to 1200 $\mu$ moles $\mathrm{Si} / 1$ is necessary for interstitial silica determinations.

\section{Procedure}

1) Have all reagents prepared.

2) Label and set up 3-dram plastic vials and caps (no precleaning needed).

3) Titrate into vials $4.0 \mathrm{ml}$ of silica-free distilled water (3.5 $\mathrm{ml}$ for standards and blank).

4) For standards and blank only, pipette in $0.5 \mathrm{ml}$ of synthetic seawater.

5) Pipette $0.5 \mathrm{ml}$ of sample or standard with Eppendorf pipette into all vials.

6) Record time. Pipette $2.0 \mathrm{ml}$ of molybdate solution, using an Eppendorf pipette, into all vials. (The solution may also be titrated in.) 
7) Wait $15 \mathrm{~min}$ for yellow color to develop.

8) Add $3 \mathrm{ml}$ of reducing solution. Record time.

9) Cap vial to reduce evaporation, shake, and wait 3 hr for blue color to develop.

10) Read on spectrophotometer at $812 \mu$.

\section{RESULTS}

Because sedimentation rates are often important in considering interstitial water chemistry (Gieskes, 1974, in press), we would like, first, to present the appropriate sedimentation rate diagram in Figure 2 (cf. also the various site reports in this volume). Basaltic basement was reached in only two of the sites investigated here, and Site 270 terminated in a buried regolith of highly altered marble and calc-silicate gneiss at 412 meters. Sites 268 and 272 showed large sedimentary thicknesses and were terminated long before reaching basement. Sedimentation rates have been variable, but were highest during the Quaternary at Site 265. Organic carbon contents at this site are high $(>0.2 \% \mathrm{C})$ in the upper 300 meters of diatomaceous oozes. Sites 265 and 274 show fairly large detrital contributions, both as clay and silt. Lithological information on the various sites is briefly summarized in the figures representing the various alkalinity profiles.

Both shipboard and shore-laboratory analytical data are presented in Table 1. The $p \mathrm{H}$ data are given to two decimals. However, they are given under shipboard conditions, i.e., at 1 atmosphere and $23^{\circ} \mathrm{C} \pm 2^{\circ}$. Thus they are, at best, qualitative data and should be used with great caution in any interpretation. Accuracies on all

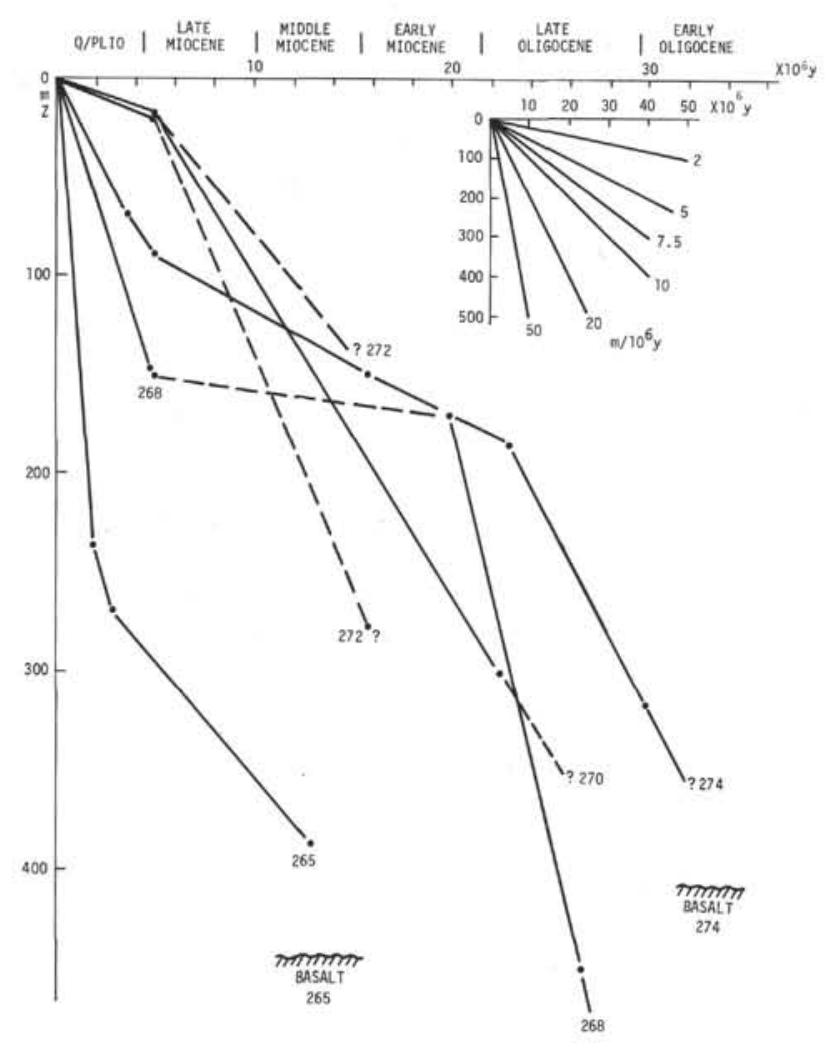

Figure 2. Sedimentation rate diagram. other data are much like those reported by Gieskes (1974), and it should be emphasized that all samples were obtained at room temperature. Temperature and pressure of squeezing artifacts do not obscure trends in gradients (Gieskes, 1974, in press). In many cases, only very small quantities of interstitial water were available, not enough for a meaningful sulfate analysis.

In the following section, the observed data will be discussed for each individual site.

\section{Site 265}

This site is characterized by extremely high sedimentation rates $(10.7 \mathrm{~cm} / 1000 \mathrm{y})$ during the Quaternary. In spite of the high sedimentation rates of this clay-bearing diatomaceous ooze and the relatively high organic carbon contents, little or no sulfate reduction occurs. The rather sparse X-ray data indicate the presence of some pyrite at 110 meters, but no specific mention of pyrite occurrence is given in the initial hole description. Postdepositional sulfate reduction processes, therefore, do not seem to be important in this site. Perhaps the depositional conditions were not favorable to sulfatereducing bacteria. The reasons for this are not well understood. Diatomaceous oozes studied in the North Pacific during Leg 19 (Sayles et al., 1973) did show fairly large depletions in sulfate in the interstitial fluids. Changes in dissolved calcium and magnesium are very small (Table 1), with a slight broad minimum for dissolved calcium.

Values of dissolved silica reflect the predominantly diatomaceous oozes. Interestingly, the temperature of squeezing effect on dissolved silica $\left(5^{\circ}\right.$ to $\left.25^{\circ} \mathrm{C}\right)$ is again about $100 \pm 50 \mu$ moles/ 1 , which implies that this effect is always very similar, whatever the absolute value of dissolved silica may be (Gieskes, in press). This negates the factor of 1.48 Schink et al. (1974) used to correct "cold" squeeze to "warm" squeeze data on dissolved silica. Values of roughly $1000 \mu$ moles/1 of $\mathrm{SiO}_{2}$, or 60 $\mathrm{ppm}$, correspond fairly well with the solubility estimates of opaline silica by Jones and Pytkowicz (1973), who give, at $2^{\circ} \mathrm{C}$, a solubility of $56 \mathrm{ppm}$ at $1 \mathrm{~atm}$ and $70 \mathrm{ppm}$ at $1000 \mathrm{~atm}$. We conclude, therefore, that the sediments at Site 265 are essentially saturated with respect to opaline silica. No chert formation or any other recrystallization process of silica has been observed at this site. In that case, good preservation of diatoms could be expected, as no further significant dissolution of silica could occur.

Values of dissolved manganese are nearly all quite large, indicating essentially reducing conditions in this hole. Some sulfate reduction may be occurring in these sediments, although not enough to cause a significant decrease in dissolved sulfate values.

A small increase in dissolved strontium with depth is evident from Table 1. This reflects, in all likelihood, slow recrystallization of calcium carbonate in the deeper part of the hole.

In general, the interstitial water data show that little postburial diagenesis has occurred at this site, at least not in the form of reactions that could affect the interstitial water composition. The absence of a significant sulfate depletion in this rapidly deposited diatomaceous ooze is especially noteworthy. 
TABLE 1

Analytical Results

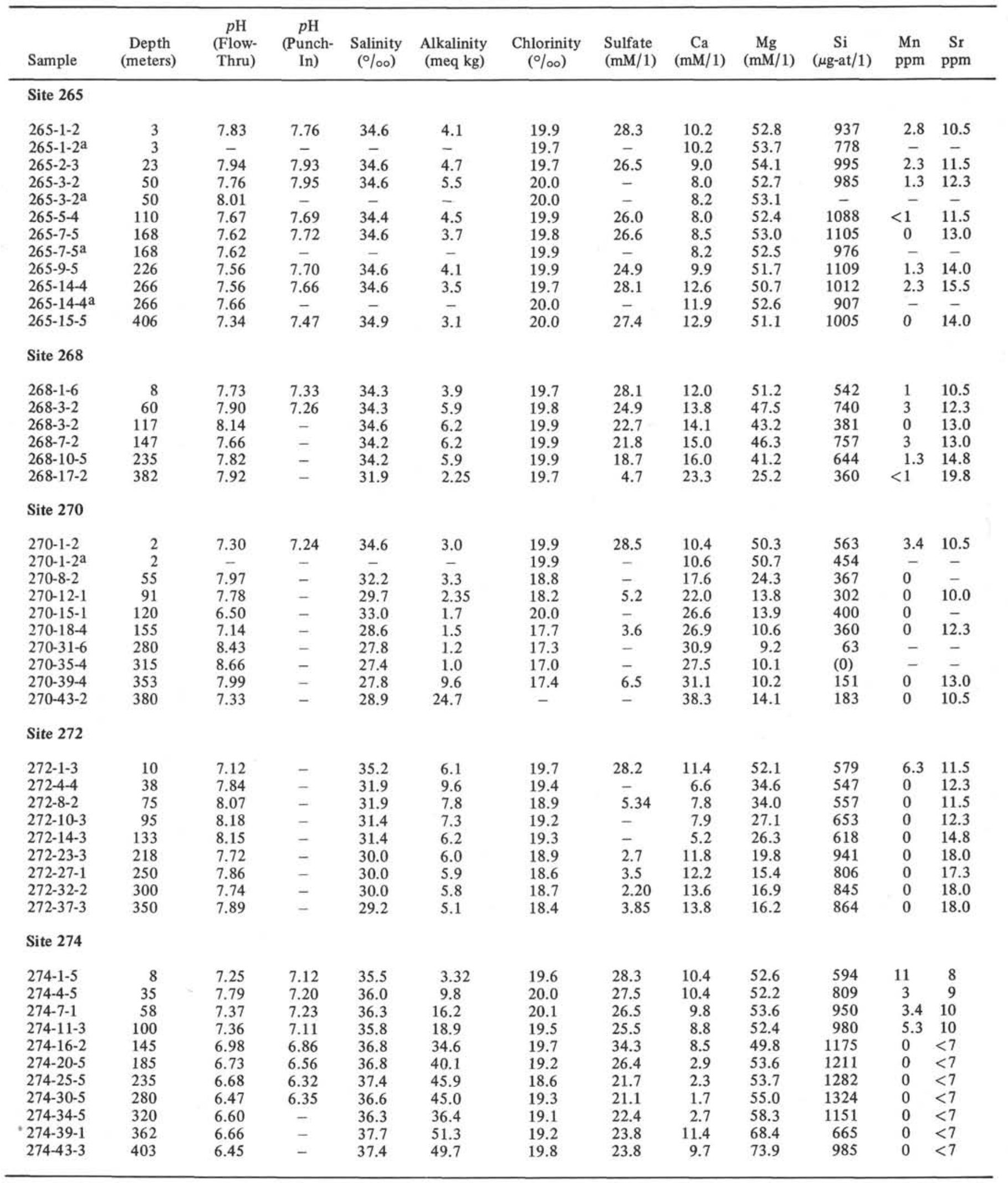

acold 


\section{Site 268}

This site is located on the lower continental rise just north of the Knox coast of Antarctica in a water depth of 2500 meters. No basement was reached in this site; however, at depths below 240 meters cherts have been found to occur. These cherty sediments show all degrees of lithification, apparently developed in diverse lithologic parent materials during the Oligocene (see site report). Data on alkalinity, dissolved sulfate, calcium and magnesium, and silica are given in Table 1 and Figures 3-6.

Dissolved sulfate decreases throughout the hole, but particularly in the deeper part of the hole. X-ray data $(467 \mathrm{~m})$ and organic carbon data also suggest that pyrite formation and sulfate reduction are still of importance in the lowermost sediments. Alkalinity shows a broad maximum, and dissolved calcium increases throughout the hole. Dissolved magnesium decreases continuously. In addition, there is a strong correlation between $\mathrm{Ca}^{++}$ and $\mathrm{Mg}^{++}$, with a change of $\Delta \mathrm{Ca}^{++} / \Delta \mathrm{Mg}^{++}=0.45$. This suggests reactions in the lowermost part of the hole, below the cored section in fact. Initial core descriptions indicate that chert occurs below 250 meters, and

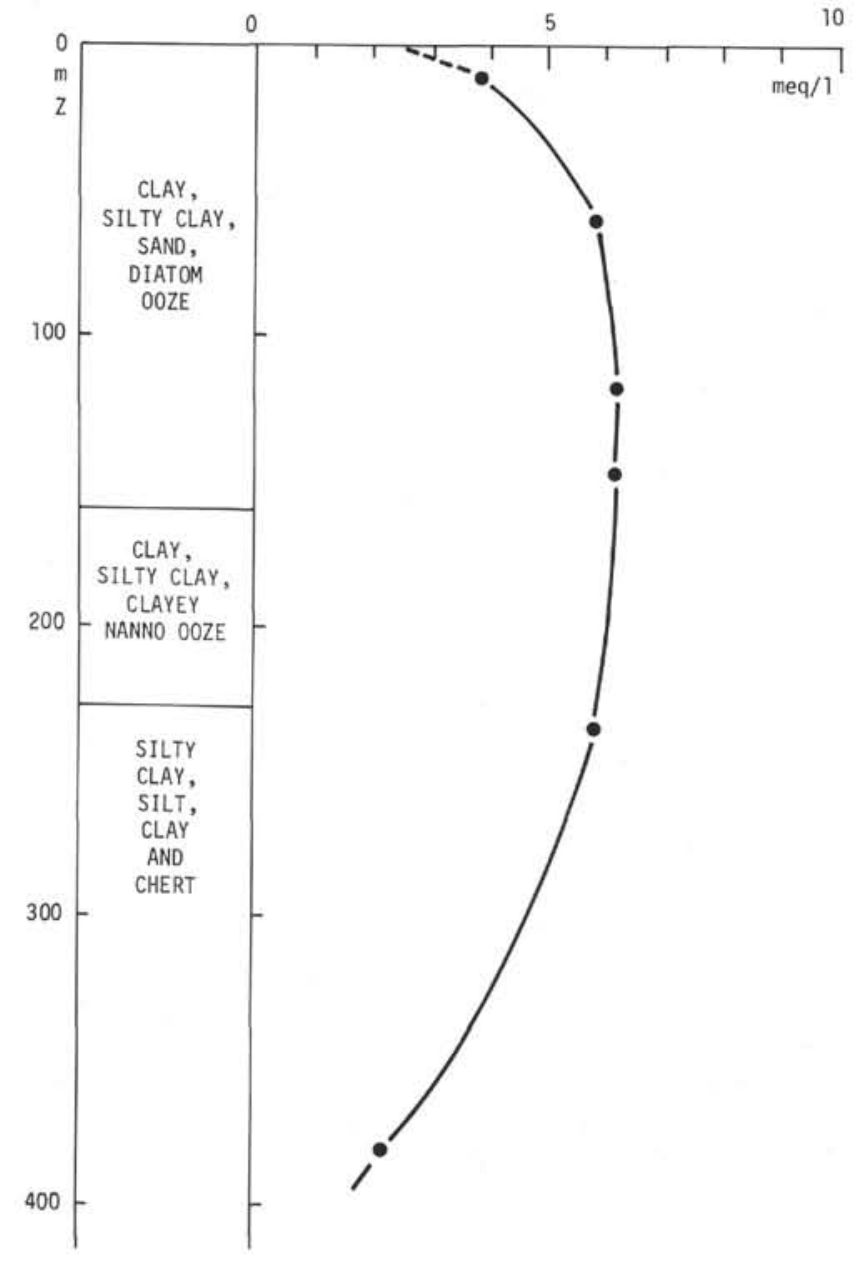

Figure 3. Alkalinity - Site 268. the X-ray data (see elsewhere in this volume) also indicate the occurrence of some cristoballite and tridymite in the section below 300 meters. No obvious diagenetic minerals were detected in the rather sparse X-ray data.

Data on dissolved silica are irregular (Table 1) and probably reflect the mixed mineralogy of this site characterized by silts, clays, and siliceous oozes.

Dissolved manganese values are relatively high and indicate the prevailing reducing conditions in the hole.

Dissolved strontium increases slightly with depth, probably related to carbonate recrystallization processes in the deeper parts of the site.

The interstitial water data of this site indicate that the postdepositional diagenetic processes are very important in this hole. Particularly in the lower part of the hole, characterized by much higher sedimentation rates (Figure 2), sulfate depletions are large. An unidentified chain of reactions in the deeper part of the site appears to involve decreases in dissolved magnesium and alkalinity and an increase in dissolved calcium.

\section{Site 270}

This site is located in the southeastern portion of the Ross Sea in a water depth of 633 meters. The hole penetrated a sedimentary sequence of 412 meters and terminated in a gneissic basement of possible early Paleozoic age.

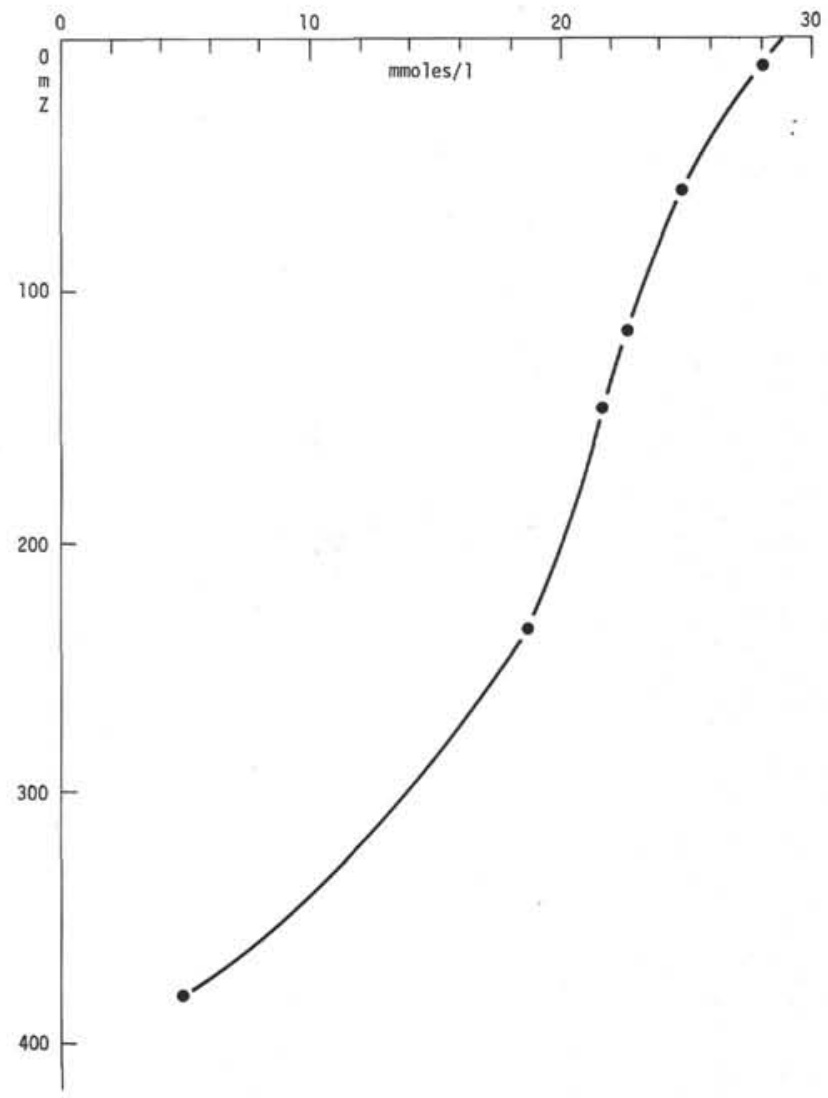

Figure 4. Sulfate-Site 268. 


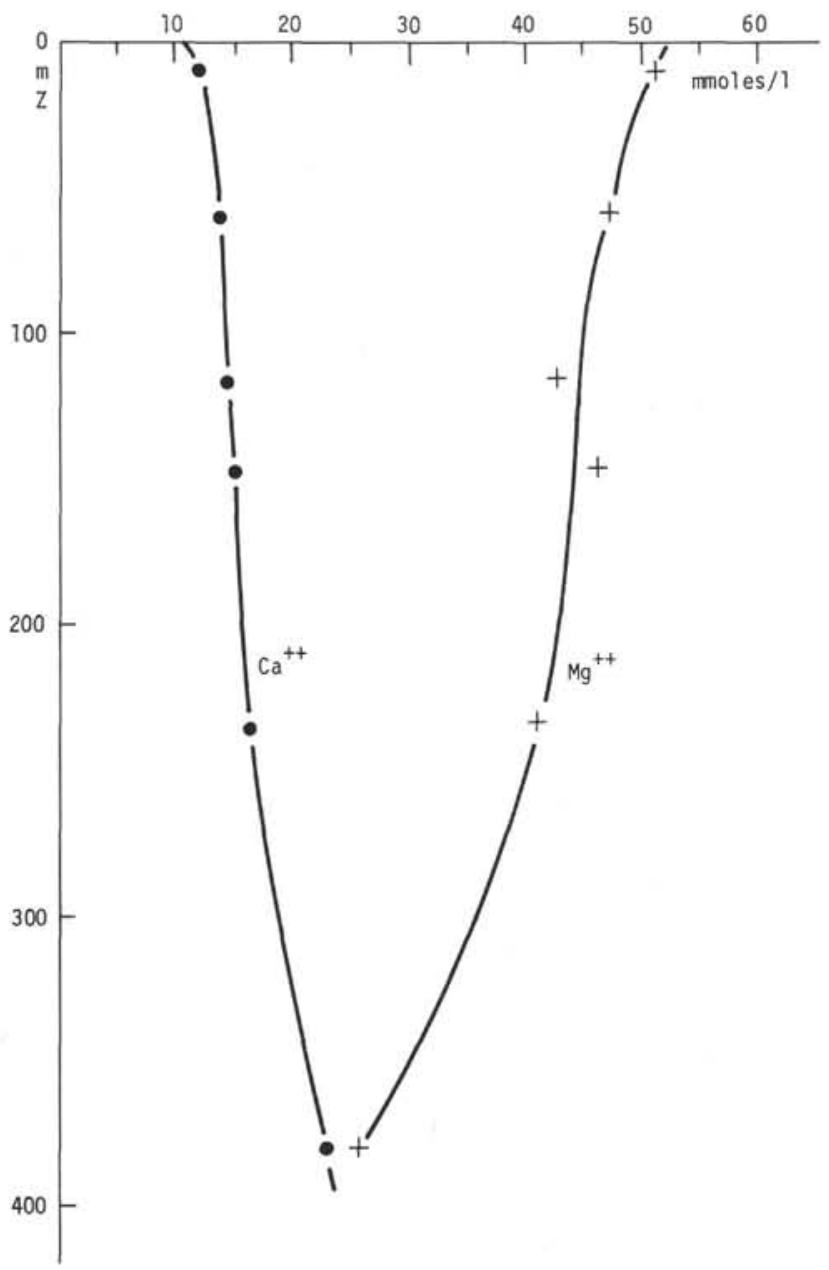

Figure 5. Calcium and magnesium - Site 268.

Shipboard salinity measurements indicated low salt contents, perhaps implying some fresh-water inflow in the lower part of this site. This contention appears to be confirmed by the chlorinity data (Figure 8 ). Chloride ion uptake by the sediment does not appear to be a likely cause for the observed decrease in chlorinity, and thus the concentration depth profile of this component appears to imply an appreciable upward advection of interstitial waters in this site, originating from below the continental basement contact with the marine sediments.

The alkalinity profile (Figure 7) at this site also is most interesting. Cristoballite and tridymite occur between 30 and 170 meters (see X-ray results). Also, dissolved sulfate shows a very sharp decrease within the first 100 meters (Figure 9), yet alkalinity values show a slight decrease below 50 meters. The fairly high $p \mathrm{H}$ values indicate a simultaneous decrease in the total $\mathrm{CO}_{2}$ content. This is not to be expected on the basis of sulfate reduction alone, which generally coincides with alkalinity increases (Manheim and Sayles, 1974; Gieskes, 1974, in press). Thus, some other process that actually decreases the alkalinity $\left(\mathrm{HCO}_{3}^{-}\right)$must be involved. The distribution of dissolved calcium and magnesium (Figure 10) is instructive with regard to this problem. In

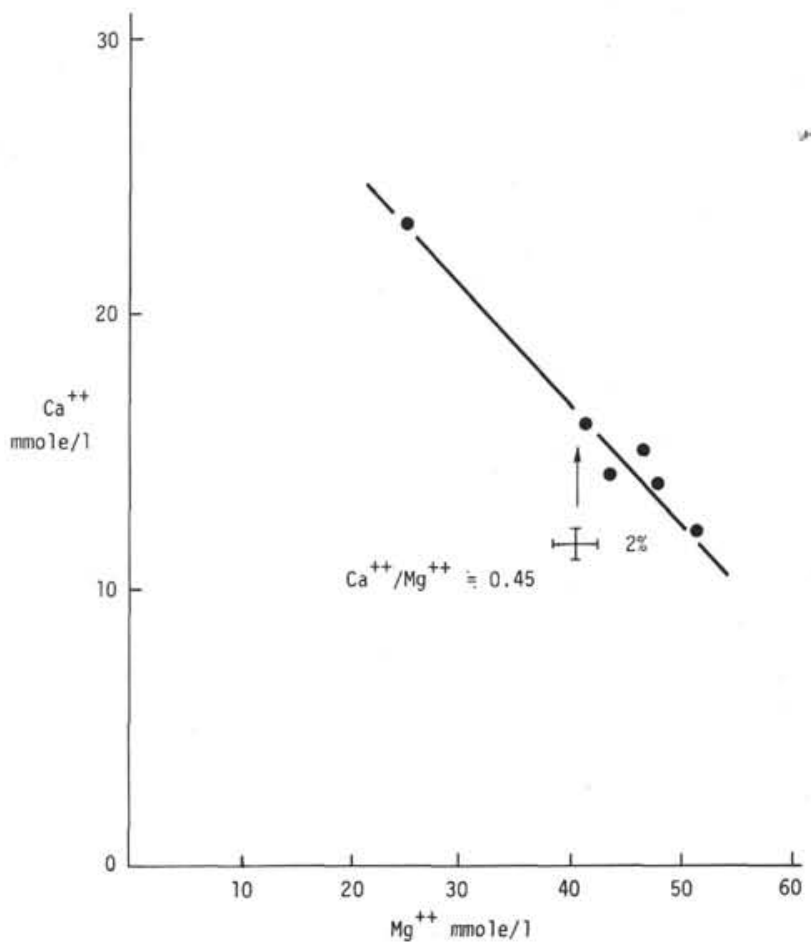

Figure 6. Calcium magnesium correlation - Site 268.

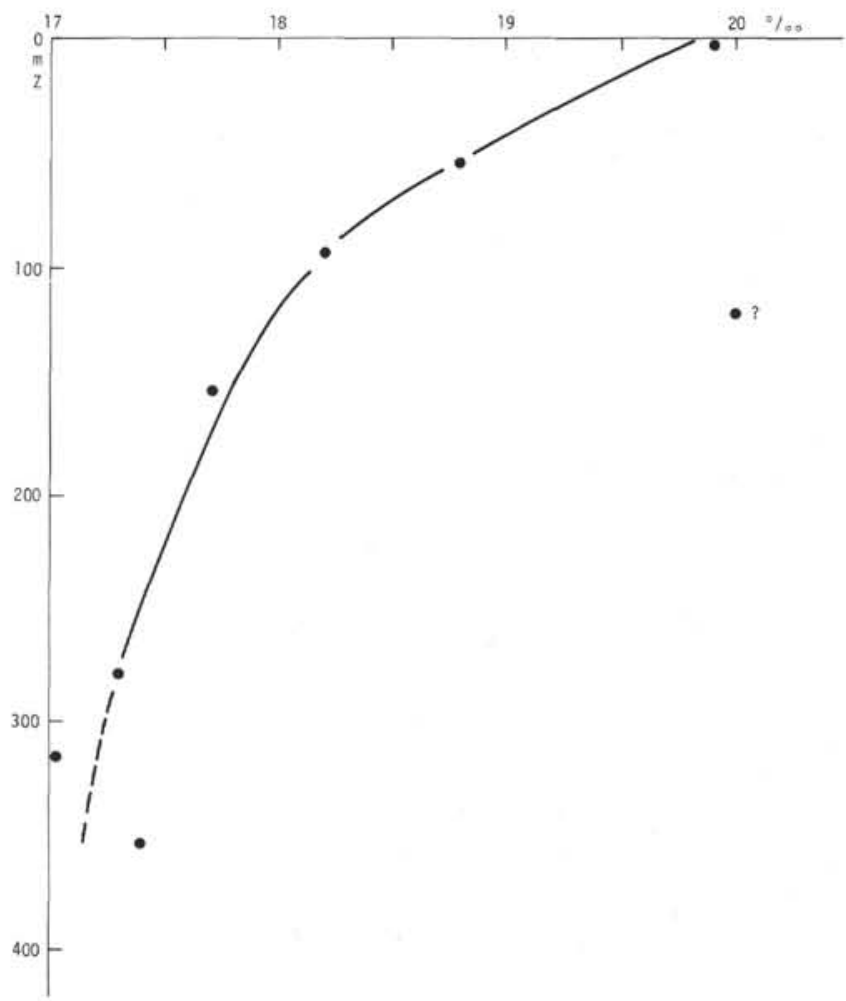

Figure 7. Chlorinity - Site 270.

the sedimentary sequence characterized by the presence of cristoballite and tridymite, sharp changes in the concentrations of these components occur. Changes in $\mathrm{Ca}^{++}$ and $\mathrm{Mg}^{++}$are not linearily correlated (Figure 11). Much 


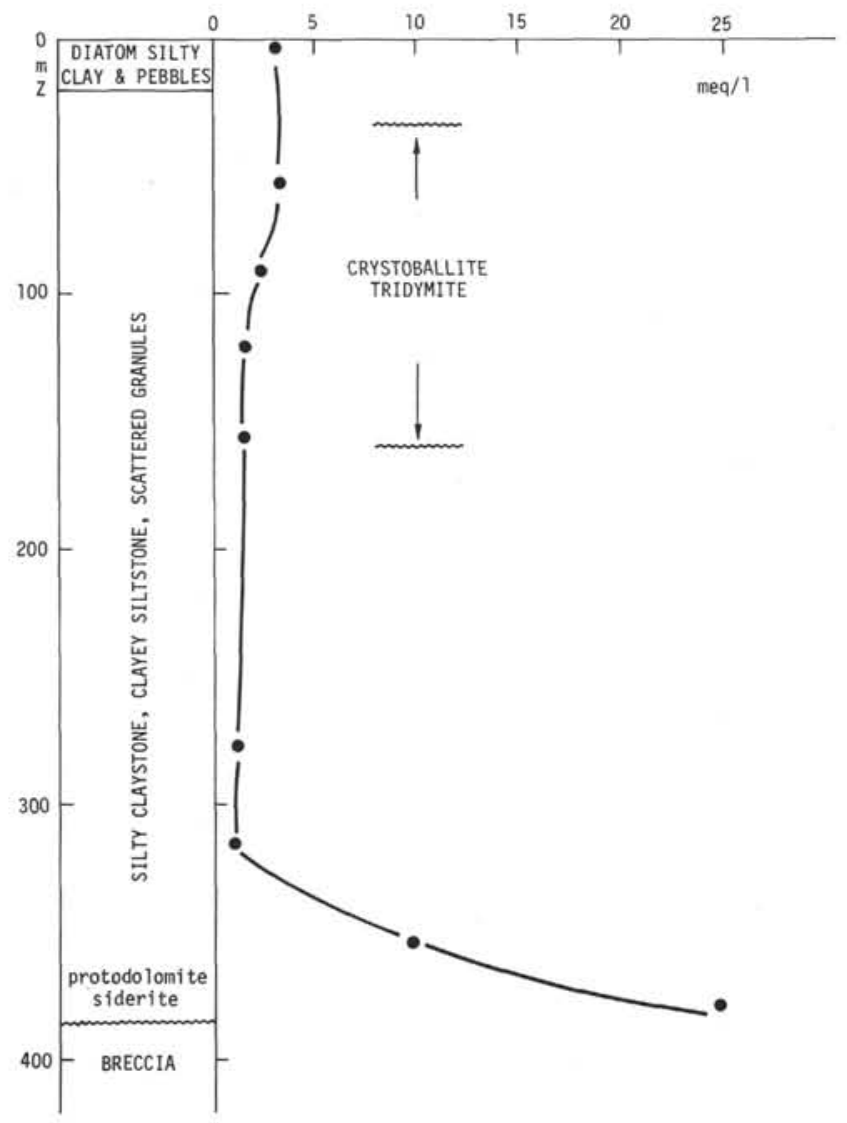

Figure 8. Alkalinity - Site 270.

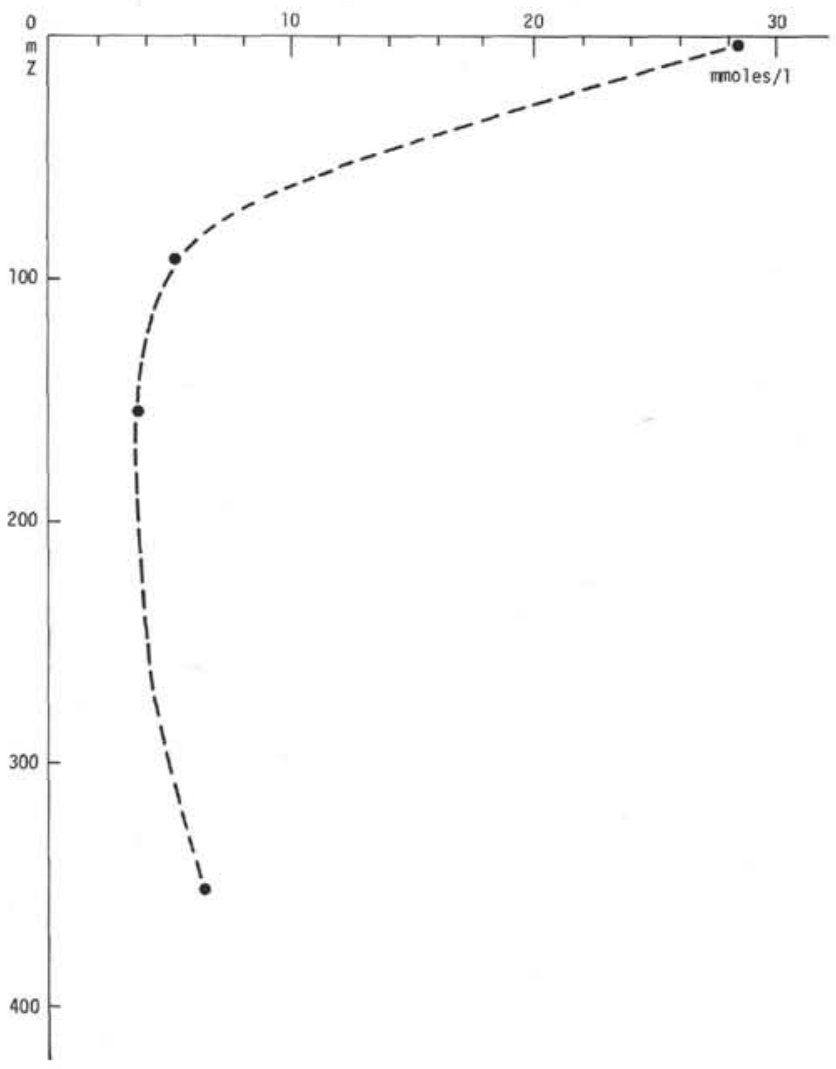

Figure 9. Sulfate - Site 270.

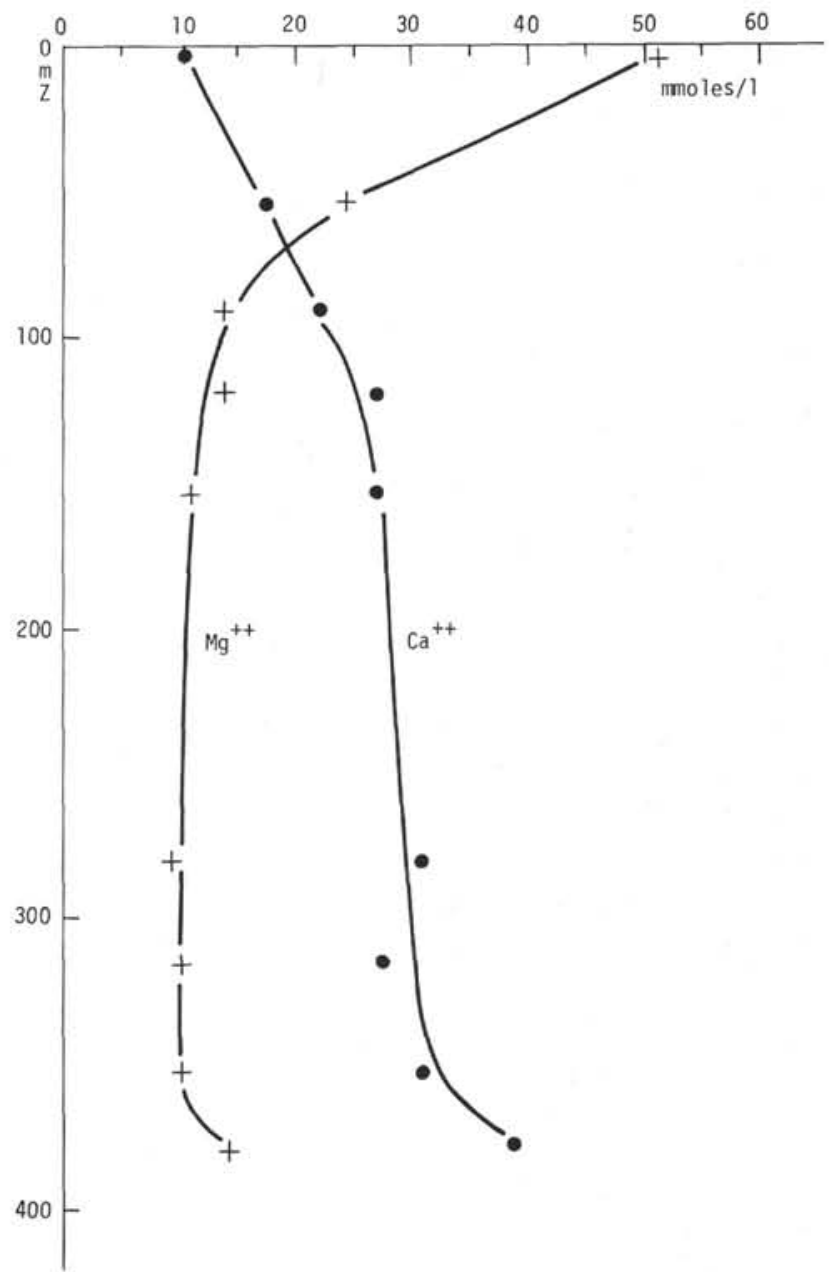

Figure 10. Calcium and magnesium - Site 270.

of the sedimentary section considered here is part of the unstratified Subunit A of Unit 2 (see site report). Granules and pebbles of ice-rafted origin comprise about $0.5 \%$ of the rock. Perhaps this material is involved in the observed diagenetic processes occurring in this sediment. Further careful work on this material seems worthwhile, but whatever the reactions involved in these sediments, they seem to be paired with the formation of cristoballite and tridymite, as well as with decreases in dissolved magnesium and alkalinity and an increase in dissolved calcium.

Another observation of some interest is the sharp increase in the alkalinity just above basement. The lowermost interstitial water sample was obtained within 10 meters from the altered basement rocks. Apparently interaction with interstitial waters of marine origin causes an increase in alkalinity. This could be related to the dissolution of carbonates. Increases in calcium (8-9 mmoles/1) and magnesium (3-4 mmoles/1) are approximately equivalent to the increase in alkalinity ( 23 $\mathrm{meq} / \mathrm{l})$. Note also that protodolomite and siderite occur just above basement (see X-ray data). Perhaps the occurrence of these materials is due to precipitation in this high alkalinity environment.

Dissolved silica values are erratic and probably reflect the lithology of this hole. 


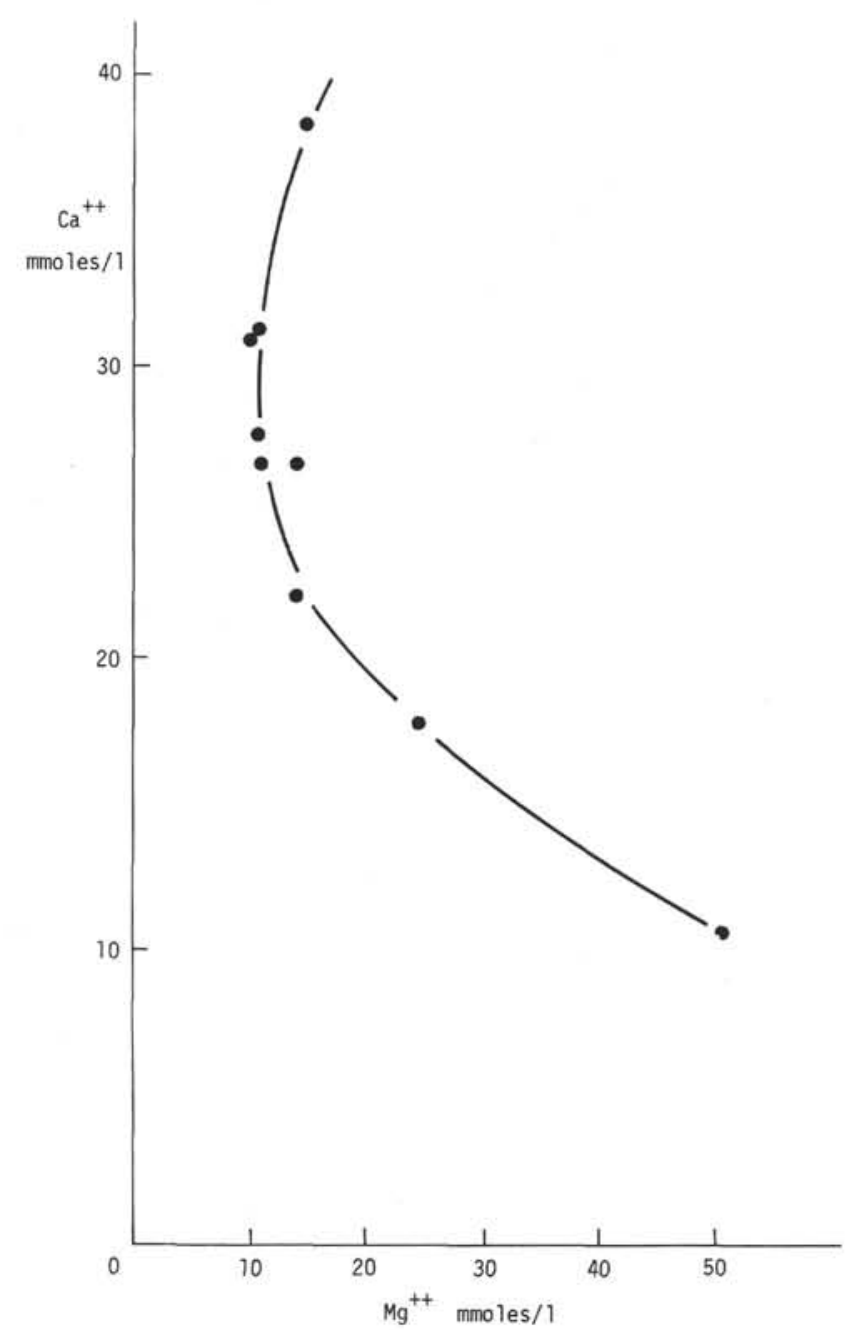

Figure 11. Calcium magnesium correlation - Site 270.

\section{Site 272}

This site is not too distant from Site 270, at a water depth of 629 meters. Thin, soft diatomaceous silty clay overlies a thick sequence of diatomaceous silty claystones. At depths between 145 and 362 meters, the diatom content increases, and this is reflected in the higher dissolved silica values (Table 1).

At this site a maximum in alkalinity occurs at about 40 meters (Figure 12), which reflects the rapid decrease with depth in dissolved sulfate (Figure 14). Also, a broad minimum in dissolved calcium occurs (calcium carbonate precipitation?) and magnesium decreases rapidly in the first 50 meters (Figure 15). Thus, from the point of view of interstitial water chemistry, this site is very different from Site 270 , in spite of their proximity (they are about 30 miles [ $48 \mathrm{~km}$ ] apart). A slight influence of fresh-water input at depth can still be noted in the chlorinity profiles (Figure 13).

The data on the chemical composition of the interstitial waters of Site 272 indicate postdepositional changes in the sediments, but no likely reactions can be suggested other than perhaps magnesium uptake by detrital silicates and sulfate reduction processes.

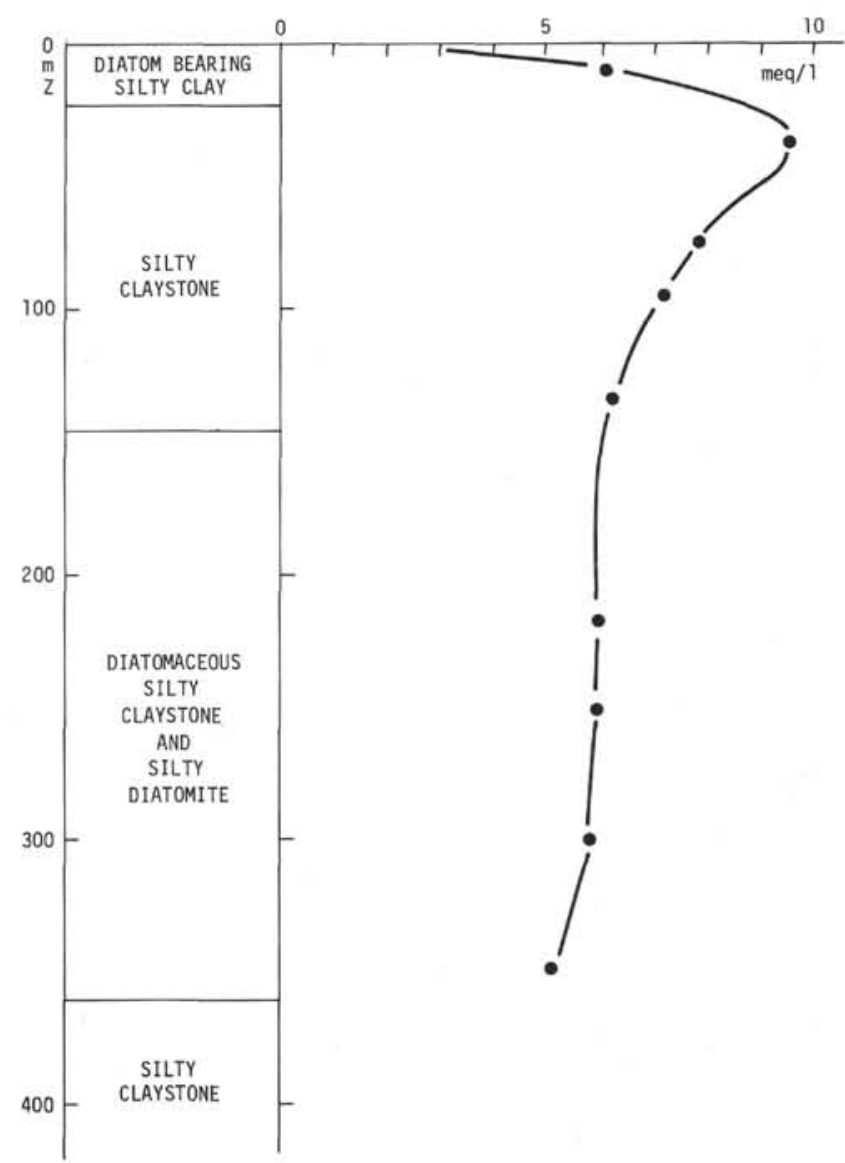

Figure 12. Alkalinity - Site 272.

Site 274

Site 274 lies about $250 \mathrm{~km}$ north-northeast of Cape Aldare, in a water depth of 3300 meters. The lithology is summarized in Figure 16.

This site is interesting because of the large increase in alkalinity with depth (Figure 16) and the concurrent small changes in dissolved sulfate (Figure 17). At the same time, total $\mathrm{CO}_{2}$ also increases, as is reflected by the decreases in $p \mathrm{H}$ (Table 1) and the presence of $\mathrm{CO}_{2}$ gas. However, no hydrocarbons were detected. Organic carbon values are high (see elsewhere in this volume), but little sulfate reduction appears to occur (cf. Site 265). It seems that the increase in alkalinity and total $\mathrm{CO}_{2}$ is related to biological processes, i.e., bacterial decomposition of organic matter, perhaps by fermentation processes. The broad minimum in dissolved calcium (Figure 18) may be related to calcium carbonate precipitation processes in the high alkalinity environment. On the other hand, dissolved magnesium increases with depth towards basement from a depth of 300 meters. Perhaps some magnesium is leached from the basalt and then precipitated as dolomite in the overlying sediments. Both dolomite $(364 \mathrm{~m})$ and siderite $(242,268$, and $364 \mathrm{~m})$ have been detected by X-ray analysis (see eslewhere in this volume).

Dissolved silica (Table 1) increases gradually downhole, reflecting an increase in diatom content (?). Below 


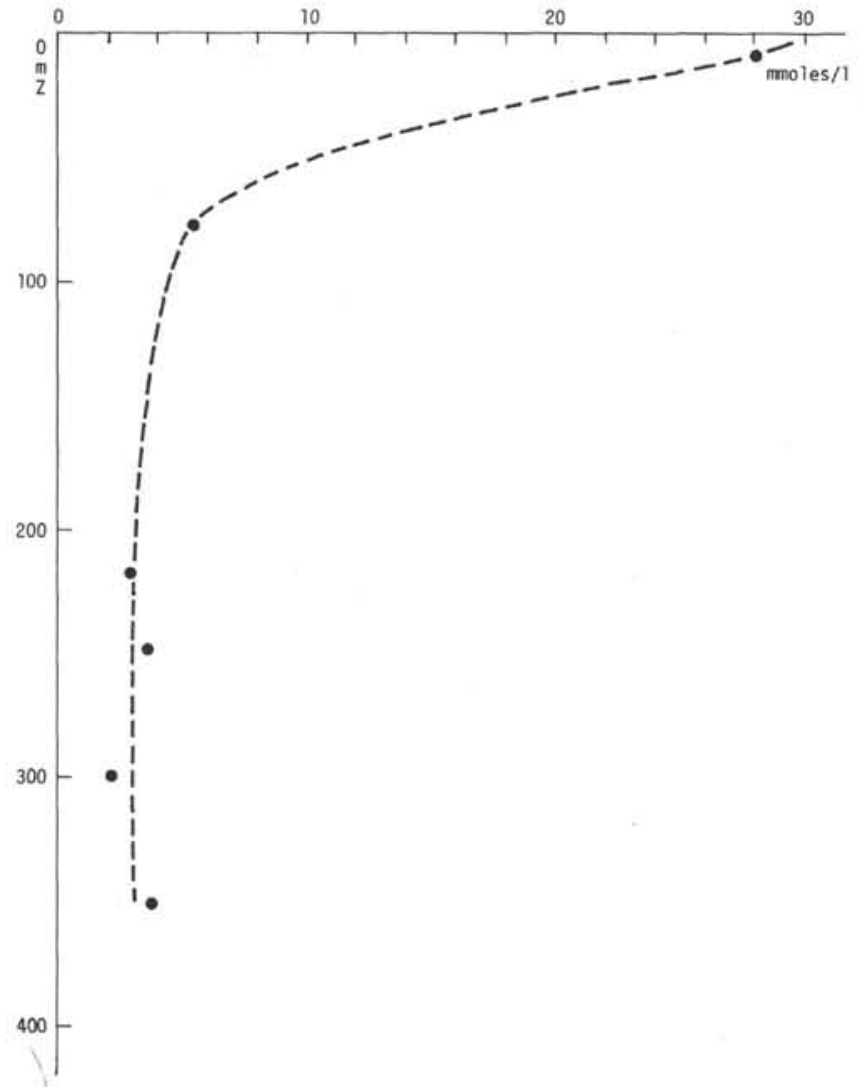

Figure 13. Sulfate - Site 272.

350 meters, dissolved silica decreases, again reflecting processes of recrystallization and chert formation.

As in all other sites, dissolved manganese is high only in the upper part of the hole. Apparently manganese is mobilized rapidly and maintained high in the upper sediments.

\section{ACKNOWLEDGMENTS}

Shipboard determinations of alkalinity, $p \mathrm{H}$, and salinity were carried out by Mr. Dennis Graham.

This work was supported by Grant NSF GA-33229.

\section{REFERENCES}

Berner, R. A., Scott, M. R., and Thomlinson, C., 1970. Carbonate alkalinity in the pore waters of anoxic marine sediments: Limnol. Oceanogr. v. 15, p. 544-549.

Gieskes, J. M., 1973. Interstitial water studies, Leg 15. Alkalinity, $p \mathrm{H}, \mathrm{Mg}, \mathrm{Ca}, \mathrm{Si}, \mathrm{PO}_{4}$, and $\mathrm{NH}_{4}$. In Heezen, $\mathrm{B}$. C., MacGregor, I. G., et al., Initial Reports of the Deep Sea Drilling Project, Volume 20: Washington (U.S. Government Printing Office), p. 813-829.

1974. Interstitial water studies, Leg 25. In Simpson, E. S. W., Schlich, R., et al., Initial Reports of the Deep Sea Drilling Project, Volume 25: Washington (U.S. Government Printing Office), p. 361-394.

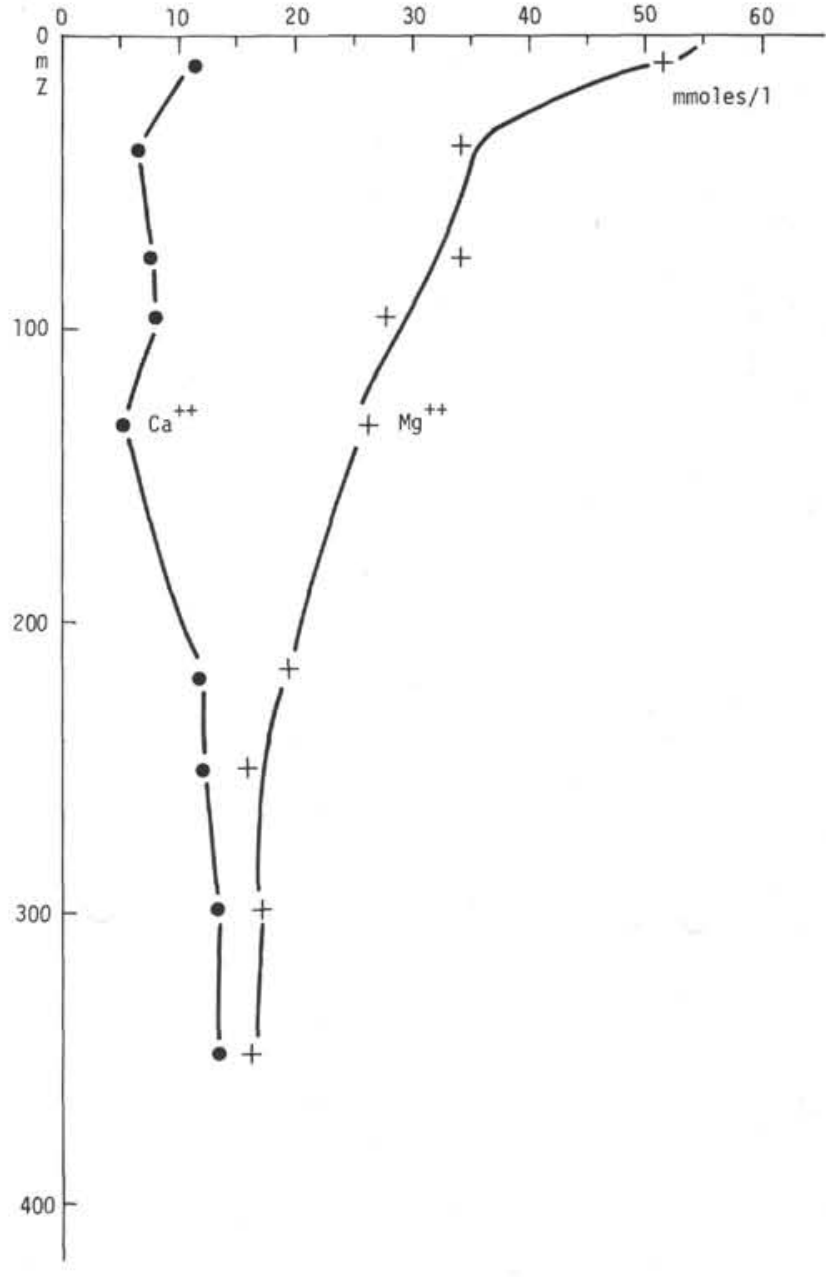

Figure 14. Calcium and magnesium - Site 272.

in press. Chemistry of interstitial waters of marine sediments: Ann. Rev. Earth Planet. Sci., v. 3.

Jones, M. M. and Pytkowicz, R. M., 1973. (Quoted by Wollast, R. M.) the silica problem. In Goldberg, E. D. (Ed.), The Sea, Volume 5: New York (Wiley-Interscience), p. 359-392.

Manheim, F. T. and Sayles, F. L., 1974. Composition and origin of interstitial waters of marine sediments, based on Deep Sea Drill cores. In Goldberg, E. D. (Ed.), The Sea: New York (Wiley-Interscience) p. 527-568.

Mullin, J. B. and Riley, J. P., 1955. The colorimetric determination of silicate with special reference to sea and natural waters: Anal. Chim. Acta, v. 12, p. 162-176.

Sayles, F. L., Waterman, L. S., and Manheim, F. T., 1973. Interstitial water studies on small core samples, Leg 19. In Creager, J. S., Scholl, D. W., et al., Initial Reports of the Deep Sea Drilling Project, Volume 19: Washington (U.S. Government Printing Office), p. 871-874.

Schink, D. R., Fanning, K. A., and Pilson, M. E. Q., 1974. Dissolved silica in the upper pore waters of the Atlantic Ocean floor: J. Geophys. Res., v. 79, p. 2243-2250. 


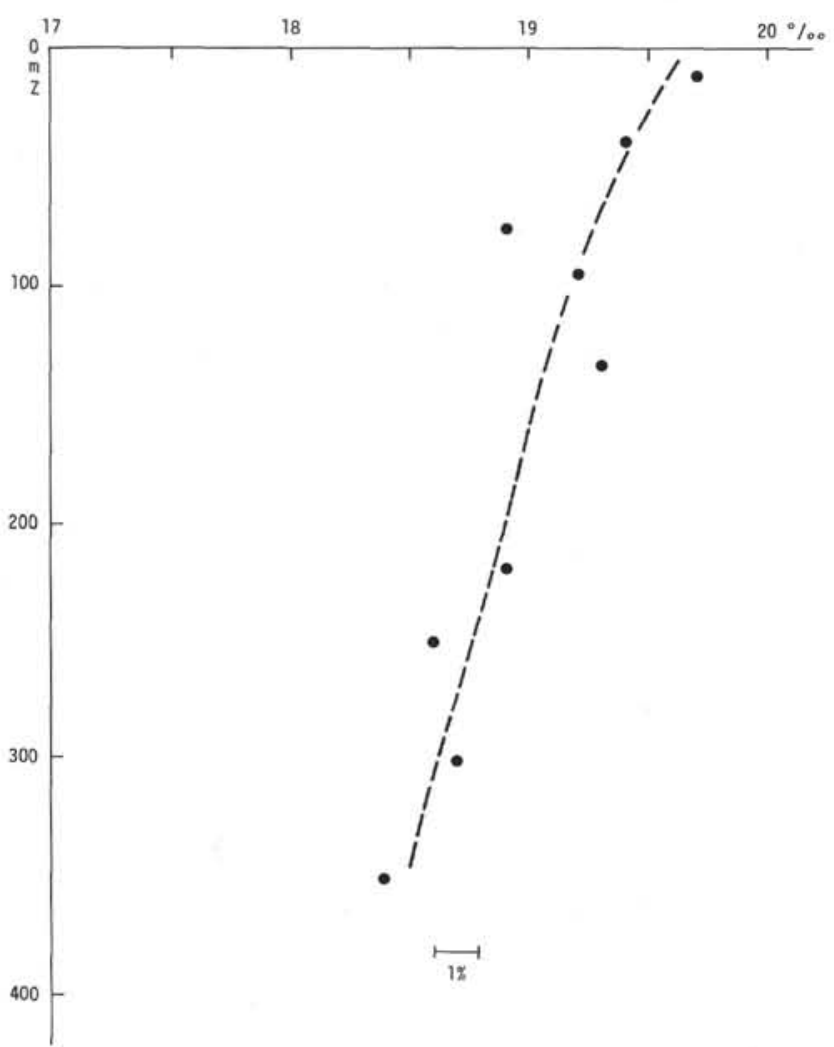

Figure 15. Chlorinity - Site 272.

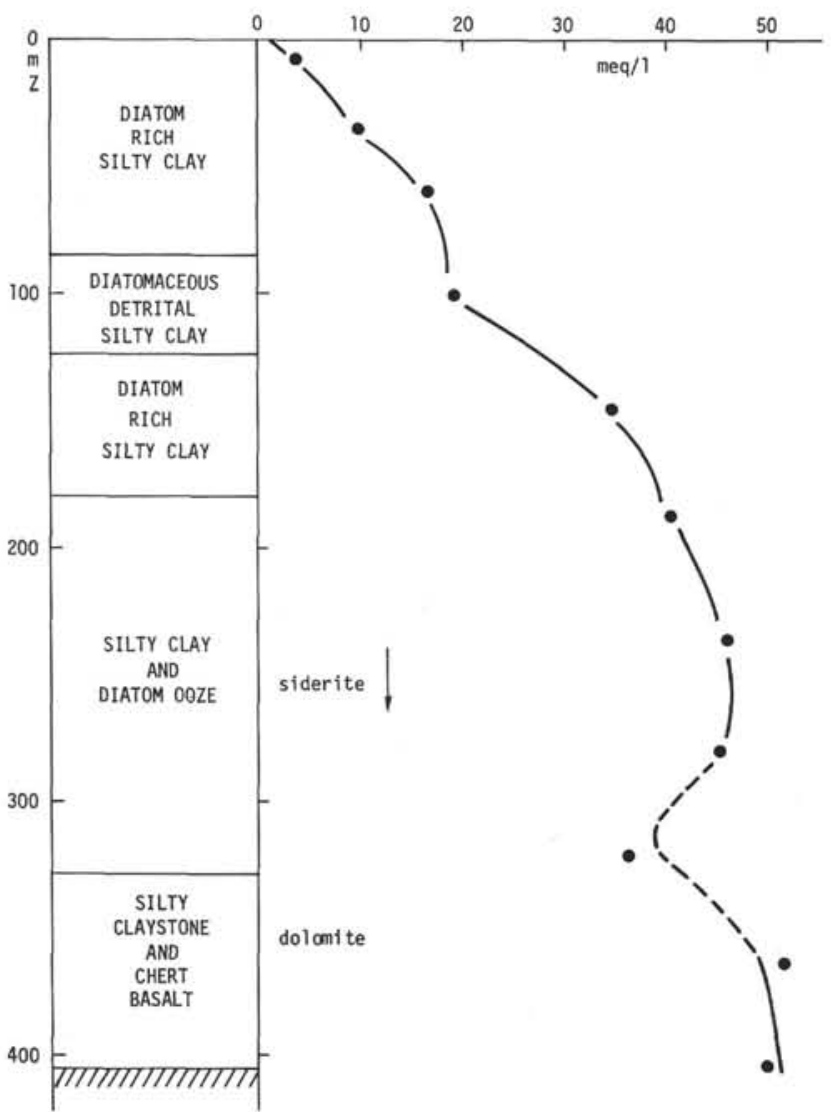

Figure 16. Alkalinity - Site 274.

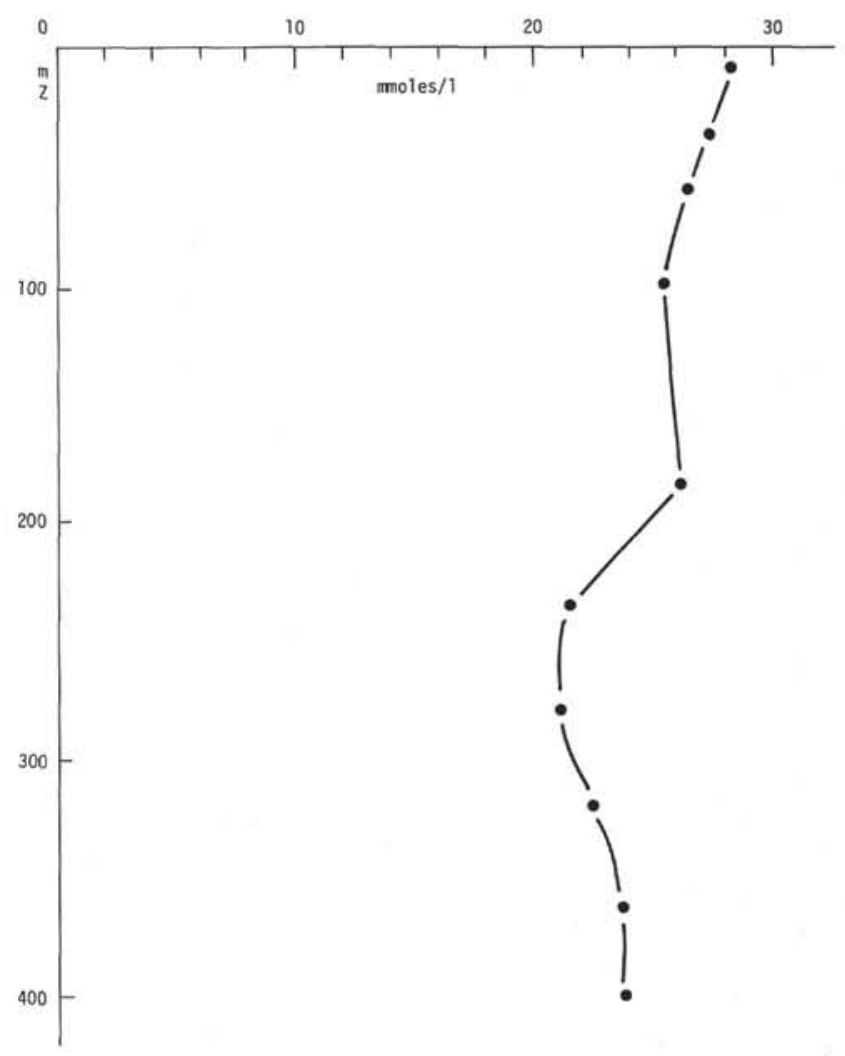

Figure 17. Sulfate - Site 274.

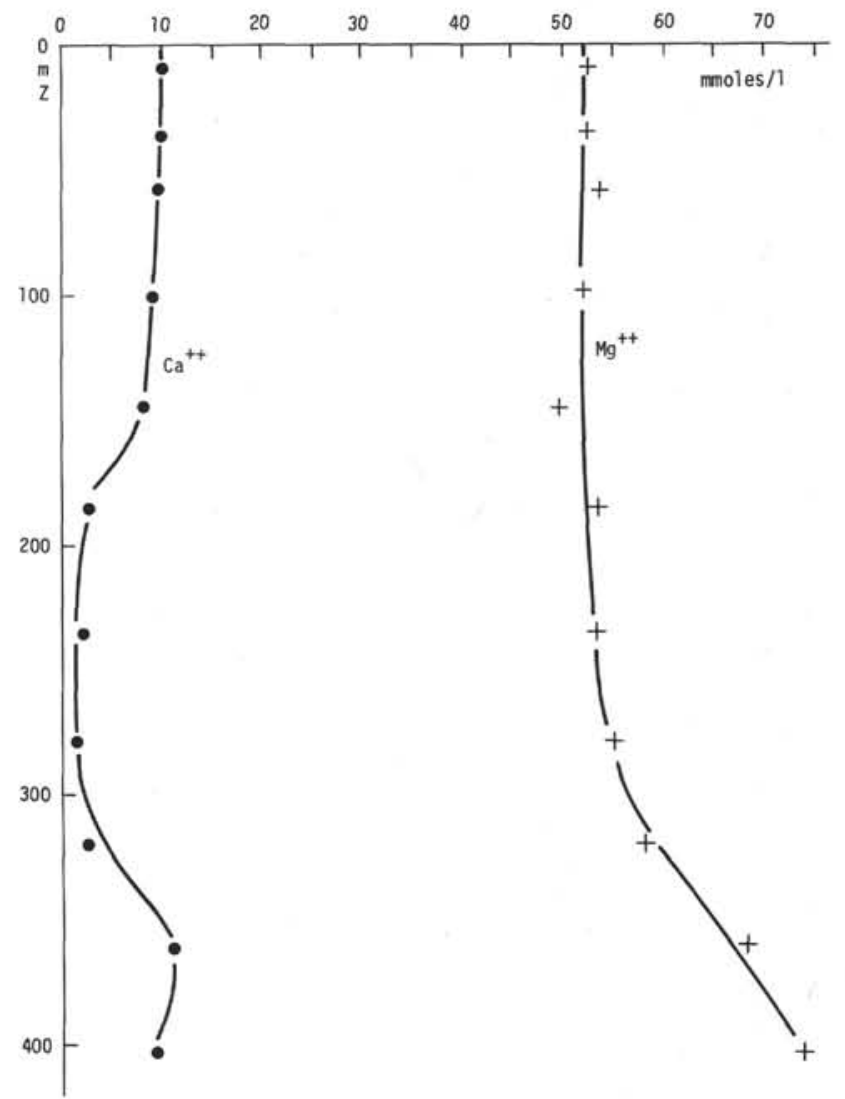

Figure 18. Calcium and magnesium - Site 274. 